\title{
Dietary magnesium requirement on dietary minerals and physiological function of juvenile hybrid sturgeon (Acipenser schrenckii $\times$ × Acipenser baerii ${ }^{\lambda}$ )
}

\author{
Yuanyuan Zhang ${ }^{1} \cdot \mathrm{Ze} \mathrm{Fan}^{1} \cdot \mathrm{Di} \mathrm{Wu}^{1} \cdot$ Jinnan $\mathrm{Li}^{1} \cdot$ Qiyou Xu $\mathrm{Xu}^{1,2} \cdot \mathrm{Hongbai}^{\mathrm{Liu}}{ }^{1} \cdot$ \\ Liansheng Wang ${ }^{1}$
}

Received: 22 June 2020 / Accepted: 27 April 2021/ Published online: 13 May 2021

(C) The Author(s) 2021

\begin{abstract}
Sturgeons are an economically important freshwater aquacultural fish in China and elsewhere. Research was conducted to study the magnesium requirement of juvenile hybrid sturgeon (Acipenser schrenckii $9 \times$ Acipenser baerii ${ }^{\Uparrow}$ ) based on mineral composition, proximate chemical analysis, antioxidant enzyme levels, and growth metrics. Different levels of magnesium supplements (43.2, 157.3, 326.5, 549.6, 743.9, 938.4, and $1118.2 \mathrm{mg} \mathrm{kg}^{-1}$ ) were fed to juvenile sturgeon for 8 weeks. Five hundred twenty-five juvenile hybrid sturgeons (an average initial body weight of $7.65 \mathrm{~g}$ ) were randomly divided into 7 groups with 3 replicates each ( 25 fish per replicate, tanks of $100 \times 50 \times 50$ $\mathrm{cm}$, dissolved oxygen $\geq 5.0 \mathrm{mg} \mathrm{L}{ }^{-1}, 12$ light: 12 dark) and fed 4 times per day with the experimental diets containing $40.78 \%$ crude protein and $10.03 \%$ crude fat. The body tissues and blood of fish were then sampled and analyzed. Growth performance was not significantly different between treatments $(P>0.05)$. The optimal dietary magnesium requirement for hybrid sturgeon was estimated to be $355.16,573.6$, or $584.6 \mathrm{mg} \mathrm{kg}^{-1}$ dietary magnesium based on whole-body $\mathrm{Mg}$ retention, the whole-body or vertebrae magnesium content versus dietary magnesium levels. The whole-body calcium to phosphorus ratio of the 43.2 and $326.5 \mathrm{mg} \mathrm{kg}^{-1}$ groups was significantly higher than that of the $938.4 \mathrm{mg} \mathrm{kg}^{-1}$ group $(P<0.05)$. A dietary magnesium concentration of $350-700 \mathrm{mg}$ $\mathrm{kg}^{-1}$ improved the antioxidant capacity by decreasing the serum malondialdehyde and enhancing serum superoxide dismutase, glutathione peroxidase, and catalase activities.
\end{abstract}

Keywords Hybrid sturgeon · Magnesium · Mineral composition · Proximate chemical analysis · Antioxidant enzymes

Handling Editor: Gavin Burnell

Liansheng Wang

wangliansheng@hrfri.ac.cn

Extended author information available on the last page of the article 


\section{Introduction}

As an essential mineral, magnesium $(\mathrm{Mg})$ has a crucial role in physiology in fish, such as the maintenance of intra- and extracellular homeostasis; numerous enzymatic processes (at least 300 enzymatic steps); nucleic acid, carbohydrate, lipid, and protein metabolism; skeletal tissue metabolism; osmoregulation; neuromuscular transmission; ion balance and exchange (Davis and Gatlin 1996; Lall 2002; Vormann 2003); tissue mineral metabolism (Zhang et al. 2016); and immune system regulation (Tam et al. 2003). Anorexia, sluggishness, reduced growth, reduced tissue $\mathrm{Mg}$ content, and vertebral deformity were the signs of Mg deficiency in fish (Lall 2002).

The $\mathrm{Mg}$ requirements of fish can be met by its uptake from water, the diet, or both (Bijvelds et al. 1997). For marine species, dietary Mg supplementation may not be necessary because $\mathrm{Mg}$ requirements can be met by uptake from seawater, where $\mathrm{Mg}$ concentrations are high (Sakamoto and Yone 1979; Ye et al. 2010; Liang et al. 2015). In contrast, if the concentration of $\mathrm{Mg}$ in freshwater is low (1-4 $\left.\mathrm{mg} \mathrm{kg}^{-1}\right)$, its uptake from the environment is considered insufficient to satisfy metabolic requirements (Lall 2002), and dietary requirements of $\mathrm{Mg}$ have been reported for several species of freshwater fish (Ogino and Chiou 1976; Gatlin et al. 1982; Shim and Ng 1988; Reigh et al. 1991; Han et al. 2012; Liang et al. 2011; Mohammad and Khan 2018).

Sturgeons are important aquatic products, not only for preserving genetic resources and extending biological diversity, but also for breeding and consumption. They are particularly important as freshwater aquaculture species with high nutritional value (CFSY, 2018). Balancing the intake of trace elements is important to ensure the health and production of sturgeon in aquaculture systems and needs further study. Thus, the aim of the current study was to estimate the dietary $\mathrm{Mg}$ requirement of juvenile hybrid sturgeon (Acipenser schrenckii + $\times$ Acipenser baerii $\left.{ }^{\top}\right)$ using growth indices supported by growth performance, body composition, mineral concentration, $\mathrm{Mg}$ balance, and plasma antioxidant function analyses.

\section{Materials and methods}

\section{Ethics statement}

All procedures involving animals were conducted according to the Guidelines for the Care and Use of Laboratory Animals of Heilongjiang River Fisheries Research Institute, Chinese Academy of Fishery Sciences (CAFS). The procedures were reviewed and approved by the Committee for the Welfare and Ethics of Laboratory Animals of Heilongjiang River Fisheries Research Institute, CAFS.

\section{Diet preparation}

The ingredients and composition of the control diet used in the study are shown in Table 1. The experimental diets were supplemented with 0 (control diet), 100, 300, 500, 700, 900, and $1100 \mathrm{mg} \mathrm{kg}^{-1} \mathrm{Mg}$ (as Mg sulfate; Sigma-Aldrich, St. Louis, MO, USA) with corresponding amounts of cellulose removed. Diets comprising dry ingredients were mixed thoroughly with distilled water and the pellets were then crushed into desirable particle sizes. The feeds were then dried and stored at $-20{ }^{\circ} \mathrm{C}$ until use. The element analysis showed final $\mathrm{Mg}$ 
Table 1 Ingredients and proximate composition of the control diet

\begin{tabular}{lc}
\hline Ingredients & $\%$ dry diet \\
\hline Casein & 40.20 \\
Gelatin & 8.00 \\
Corn starch & 35.68 \\
Fish oil & 5.00 \\
Soybean oil & 5.00 \\
Cellulose & 3.30 \\
Monocalcium phosphate & 2.00 \\
Choline chloride & 0.20 \\
Betaine & 0.10 \\
Butylated hydroxytoluene & 0.02 \\
Mineral premix & 0.20 \\
Vitamin premix & \\
Proximate composition $(\%)$ & 0.30 \\
Crude protein & 40.78 \\
Crude fat & 10.03 \\
Crude ash & 3.74 \\
\hline
\end{tabular}

a The mineral premix provided the following per kg of diet: zinc, $60 \mathrm{mg}$; copper, $3 \mathrm{mg}$; iron, $25 \mathrm{mg}$; manganese, $15 \mathrm{mg}$; iodine, $0.6 \mathrm{mg}$; and selenium, $0.30 \mathrm{mg}$

$\mathrm{b}$ The vitamin premix provided the following per $\mathrm{kg}$ of diet: vitamin $\mathrm{A}, 8000 \mathrm{IU}$; vitamin $\mathrm{C}, 500 \mathrm{mg}$; vitamin D, 33,000 IU; vitamin E, 60 mg; vitamin K, 35 mg; vitamin B1, 15 mg; vitamin B2, 30 mg; vitamin B6, 15 mg; vitamin B12, $0.5 \mathrm{mg}$; choline chloride, $5000 \mathrm{mg}$; nicotinic acid, $175 \mathrm{mg}$; D-biotin, $2.5 \mathrm{mg}$; inositol, $1000 \mathrm{mg}$; folic acid, $5 \mathrm{mg}$; and pantothenic acid, $50 \mathrm{mg}$

concentrations of $43.2,157.3,326.5,549.6,743.9,938.4$, and $1118.2 \mathrm{mg} \mathrm{kg}^{-1}$ dry diet, and the distilled water was found to contain $2.8 \mathrm{mg} \mathrm{L}^{-1} \mathrm{Mg}$. The concentrations of other essential elements in the diet, calcium (Ca) and phosphorus (P), are shown in Table 2. Element analysis of the experimental diets following the method of Ye et al. (2010) was performed to determine the final $\mathrm{Mg}$ concentrations. Feed samples of approximately $0.10-0.15 \mathrm{~g}$ were digested with $15 \mathrm{~mL}$ 65-68\% nitric acid and $2 \mathrm{~mL} \mathrm{72 \%} \mathrm{perchloric} \mathrm{acid} \mathrm{using} \mathrm{Kjeldahl} \mathrm{flasks.} \mathrm{After}$ digestion, samples were diluted to $50 \mathrm{~mL}$ and their $\mathrm{Ca}, \mathrm{P}$, and $\mathrm{Mg}$ contents analyzed by using an inductively coupled plasma atomic emission spectrophotometer. The standard solution was provided by Nanjing Jiancheng Bioengineering Institute (Nanjing, China). The analysis of $\mathrm{Mg}$ in water was performed using an atomic absorption spectrometer (Nthunya et al., 2018). The analysis was performed under an air pressure of $28 \mathrm{psi}$, a fuel (acetylene) pressure of $8 \mathrm{psi}$, and a sample uptake of $4 \mathrm{~mL}$. The samples were filtered using $0.45-\mu \mathrm{m}$ filters and $0.4 \mathrm{~mL}$ of NaCl-

Table 2 Mg supplement and mineral content analysis of experimental diets

\begin{tabular}{|c|c|c|c|}
\hline \multirow[t]{2}{*}{$\mathrm{Mg}\left(\mathrm{mg} \mathrm{kg}^{-1}\right)$} & \multicolumn{3}{|c|}{ Analyzed content } \\
\hline & $\operatorname{Mg}\left(\mathrm{mg} \mathrm{kg}^{-1}\right)$ & $\mathrm{Ca}\left(\mathrm{g} \mathrm{kg}^{-1}\right)$ & $\mathrm{P}\left(\mathrm{g} \mathrm{kg}^{-1}\right)$ \\
\hline 0 & $43.2 \pm 2.1$ & $7.71 \pm 0.24$ & $6.85 \pm 0.14$ \\
\hline 100 & $157.3 \pm 1.8$ & $8.28 \pm 0.25$ & $6.77 \pm 0.16$ \\
\hline 300 & $326.5 \pm 11.8$ & $8.06 \pm 0.23$ & $7.03 \pm 0.20$ \\
\hline 500 & $549.6 \pm 16.9$ & $7.53 \pm 0.17$ & $6.98 \pm 0.15$ \\
\hline 700 & $743.9 \pm 22.0$ & $8.02 \pm 0.20$ & $6.54 \pm 0.09$ \\
\hline 900 & $938.4 \pm 12.9$ & $8.47 \pm 0.24$ & $6.76 \pm 0.09$ \\
\hline 1100 & $1118.2 \pm 32.6$ & $8.25 \pm 0.18$ & $6.79 \pm 0.13$ \\
\hline
\end{tabular}

Values represent means $\pm \mathrm{SD}, n=3$ 
$\mathrm{HCl}$ was added to each sample before analysis. The percentage absorption was converted to absorbance, which was subsequently used to calculate the concentration of each element. Proximate analyses (crude protein, crude fat, and crude ash) of diets were performed according to methods of the Association of Official Analytical Chemists (AOAC, 1995). In brief, the dry matter content was dried to constant weight at $105{ }^{\circ} \mathrm{C}$ and the crude protein content was determined by the Kjeldahl method after acid digestion. The crude fat content was determined through the ether extraction method using a Soxhlet device, and the samples were placed into a muffle furnace at $550{ }^{\circ} \mathrm{C}$ for $8 \mathrm{~h}$ for ash content analysis.

\section{Fish and experimental conditions}

Juvenile hybrid sturgeons were obtained from the Fangshan Breeding Center (Beijing, China). The fish were transferred to an indoor aquarium and acclimated for 2 weeks, during which they were fed a control diet. The temperature ranged from 21 to $23{ }^{\circ} \mathrm{C}$, the dissolved oxygen was not less than $5.0 \mathrm{mg} \mathrm{L}^{-1}$, the photoperiod was 12 light:12 dark, and the water was changed every 3 days. The tanks were filled with a continuously aerated mixture of tap water. After 2 weeks, 28 juvenile hybrid sturgeons (an average weight of $7.65 \mathrm{~g}$ ) were then randomly assigned into one of 21 tanks of $100 \times 50 \times 50 \mathrm{~cm}$. Three fish per tank were used to analyze the initial whole-body $\mathrm{Mg}$ at the beginning of the trial. The remaining 25 fish were weighed inbulk (initial body weight (IBW)) and formed the experimental group in each tank. Seven diets were randomly assigned to three replicate tanks. The diets were fed by hand to apparent satiation at 07:00 h, 11:00 h, 16:00 h, and 19:00 h based on visual observations of the fish feeding behavior. Water quality was regularly monitored weekly and no differences were recorded among tanks throughout the experimental period.

During the 8-week experimental period, the feed conversion ratio (FCR) was determined by feed intake (g)/body weight gain. Uneaten feed particles were dried and weighed and used for correction of the feed consumption rate.

At the end of the trial, all of the fish were deprived of feed for $24 \mathrm{~h}$ and then the fish from each replicate were weighed (final body weight (FBW)). Weight gain rate (WG, \%) was calculated as $100 \times[$ final weight $(\mathrm{g})-$ initial weight $(\mathrm{g})] /$ initial weight $(\mathrm{g})$.

\section{Sample collection and analyses}

At the end of the 8-week feeding trial, six fish per tank were anesthetized with MS-222 $(250 \mathrm{mg} / \mathrm{L})$ and three of these were then used to analyze the whole-body composition; the other three were used to analyze the whole-body $\mathrm{Mg}, \mathrm{Ca}$, and $\mathrm{P}$ concentrations. All six fish were stored at $-80{ }^{\circ} \mathrm{C}$ before use. Another three fish per tank were anesthetized and dissected on an ice plate, and their vertebrae were removed from the surrounding tissues and rinsed with distilled water, dried, ground, and stored at $-40{ }^{\circ} \mathrm{C}$ for $\mathrm{Mg}, \mathrm{Ca}$, and $\mathrm{P}$ analyses. Blood of another six fish per tank was taken immediately following euthanasia and collected by 1-mL disposable heparinized syringes through the caudal vasculature of each fish, transferred into a disposable Eppendorf tube, centrifuged at $4000 \times g\left(4{ }^{\circ} \mathrm{C}\right)$ for $15 \mathrm{~min}$ to obtain the serum samples (two mixed into one), and then immediately stored at $-20{ }^{\circ} \mathrm{C}$ until analysis.

The whole-body crude protein, crude fat, dry matter, and ash contents were determined following the procedures of AOAC (1995) as the same descriptions as proximate analyses of diets. The $\mathrm{Mg}, \mathrm{Ca}$, and $\mathrm{P}$ concentrations in whole body and vertebrae were measured using the 
method of Ye et al. (2010). The indexes correlated with whole-body Mg retention (Lin et al., 2013) were calculated as follows:

$$
\begin{aligned}
\text { Initial whole-body } \mathrm{Mg} \text { content }(\mathrm{mg})= & \text { initial whole-body } \mathrm{Mg} \text { concentration }(\mathrm{mg} / \mathrm{g}) \\
& \times \text { initial body weight }(\mathrm{g})
\end{aligned}
$$

Total $\mathrm{Mg}$ fed $(\mathrm{mg})=$ feed $\mathrm{Mg}$ concentration $(\mathrm{mg} / \mathrm{g}) \times$ total feed intake $(\mathrm{g})$

Final whole-body content $(\mathrm{mg})=$ final whole-body $\mathrm{Mg}$ concentration $(\mathrm{mg} / \mathrm{g})$

$\times$ final body weight $(\mathrm{g})$

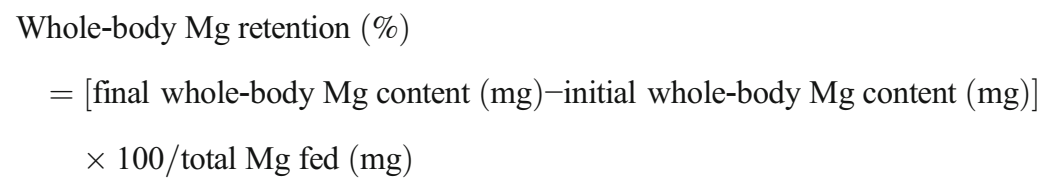

The serum was used to determine the superoxide dismutase (SOD) (A001-3-2, hydroxylamine method), glutathione peroxidase (GPx) (A005-1, colorimetric method), and catalase (CAT) (A007-1-1, ultraviolet) activities and malondialdehyde (MDA) (A003-1, thiobarbituric acid method) content. All of these indices were determined using commercial kits supplied by Nanjing Jiancheng Bioengineering Institute. The activities and content were measured according to the kit protocols provided in the manufacturer's instructions.

\section{Statistical analyses}

The data were subjected to one-way analysis of variance (ANOVA) using SPSS 22.0 (SPSS, Chicago, IL, USA) and are presented as the means \pm SD. Differences in the means between dietary treatments were evaluated using Duncan's multiple range tests. The optimum dietary $\mathrm{Mg}$ requirements, including relationship between the whole-body $\mathrm{Mg}$ concentration and dietary $\mathrm{Mg}$ as well as relationship between the vertebrae $\mathrm{Mg}$ concentration and dietary $\mathrm{Mg}$, were estimated using the broken line model (Robbins et al. 1979). The relationships between whole-body $\mathrm{Mg}$ retention and dietary $\mathrm{Mg}$ levels were estimated by power function analysis.

\section{Results}

\section{Growth performance}

The growth performance of juvenile hybrid sturgeon fed the experimental diets for 8 weeks is shown in Table 3. The effects of the dietary Mg levels on IBW, FBW, WG, and FCR were not significantly different between treatments $(P>0.05)$. 
Table 3 Growth performances of juvenile hybrid sturgeon fed experimental diets containing different $\mathrm{Mg}$ concentrations for 8 weeks

\begin{tabular}{lllll}
\hline $\mathrm{Mg}\left(\mathrm{mg} \mathrm{kg}^{-1}\right)$ & IBW $(\mathrm{g})$ & FBW $(\mathrm{g})$ & WG $(\%)$ & FCR \\
\hline $0(43.2)$ & $7.68 \pm 0.16$ & $17.06 \pm 1.64$ & $121.95 \pm 20.08$ & $1.34 \pm 0.05$ \\
$100(157.3)$ & $7.67 \pm 0.08$ & $17.90 \pm 1.77$ & $133.32 \pm 15.37$ & $1.37 \pm 0.03$ \\
$300(326.5)$ & $7.62 \pm 0.10$ & $19.83 \pm 1.65$ & $160.12 \pm 21.16$ & $1.34 \pm 0.85$ \\
$500(549.6)$ & $7.63 \pm 0.05$ & $20.29 \pm 1.88$ & $166.01 \pm 16.38$ & $1.32 \pm 0.12$ \\
$700(743.9)$ & $7.65 \pm 0.24$ & $20.29 \pm 1.44$ & $165.47 \pm 21.60$ & $1.30 \pm 0.08$ \\
$900(938.4)$ & $7.63 \pm 0.16$ & $19.99 \pm 1.94$ & $162.16 \pm 18.65$ & $1.32 \pm 0.11$ \\
$1100(1118.2)$ & $7.63 \pm 0.23$ & $20.00 \pm 1.90$ & $162.58 \pm 12.23$ & $1.37 \pm 0.11$ \\
\hline
\end{tabular}

Values represent means $\pm \mathrm{SD}, n=3$

$I B W$ initial body weight, $F B W$ final body weight, $W G$ weight gain rate, $F C R$ feed conversion ratio

\section{Whole-body composition}

The whole-body compositions of juvenile hybrid sturgeon fed the experimental diets containing different $\mathrm{Mg}$ levels for 8 weeks are shown in Table 4. Compared with $43.2 \mathrm{mg} \mathrm{kg}^{-1}$ (control), $743.9 \mathrm{mg} \mathrm{kg}^{-1} \mathrm{Mg}$ significantly decreased the body moisture of hybrid sturgeon and significantly increased the crude protein content $(P<0.05)$. The fish fed $43.2 \mathrm{mg} \mathrm{kg}^{-1}$ exhibited lower crude fat levels than the other groups $(P<0.05)$. Fish provided with diets containing 549.6-1118.2 mg kg-1 had higher ash concentrations than the group given the control feed (43.2 $\left.\mathrm{mg} \mathrm{kg}^{-1}\right)$.

\section{Whole-body and vertebrae mineral concentration}

The whole-body and vertebrae $\mathrm{Ca}$ and $\mathrm{P}$ concentrations of juvenile hybrid sturgeon fed the experimental diets containing different $\mathrm{Mg}$ levels for 8 weeks are shown in Table 5. The whole-body $\mathrm{Ca}$ and $\mathrm{P}$ concentrations exhibited no significant differences among all the groups $(P>0.05)$. The Ca:P ratios in the 43.2 and $326.5 \mathrm{mg} \mathrm{kg}^{-1}$ groups were significantly higher than those in the $938.4 \mathrm{mg} \mathrm{kg}^{-1}$ group $(P<0.05)$. The Ca concentrations of the vertebrae in the $157.3-743.9 \mathrm{mg} \mathrm{kg}^{-1}$ groups were significantly higher than those in the $1118.2 \mathrm{mg} \mathrm{kg}^{-1}$ group $(P<0.05)$. The Ca:P ratio in the 43.2 and $157.3 \mathrm{mg} \mathrm{kg}^{-1}$ groups was significantly higher than that in the 938.4 and $1118.2 \mathrm{mg} \mathrm{kg}^{-1}$ groups $(P<0.05)$ and significantly higher in the $326.5 \mathrm{mg} \mathrm{kg}^{-1}$ group than in the $1118.2 \mathrm{mg} \mathrm{kg}^{-1}$ group $(P<0.05)$.

Table 4 Whole-body composition (\%) of juvenile hybrid sturgeon fed experimental diets containing different $\mathrm{Mg}$ concentrations for 8 weeks

\begin{tabular}{lllll}
\hline Mg (mg kg-1) & Moisture & Crude protein & Crude fat & Ash \\
\hline $0(43.2)$ & $80.07 \pm 0.44^{\mathrm{a}}$ & $12.99 \pm 0.42^{\mathrm{b}}$ & $3.75 \pm 0.19^{\mathrm{b}}$ & $2.86 \pm 0.05^{\mathrm{b}}$ \\
$100(157.3)$ & $79.25 \pm 0.47^{\mathrm{ab}}$ & $13.42 \pm 0.33^{\mathrm{ab}}$ & $4.36 \pm 0.08^{\mathrm{a}}$ & $3.17 \pm 0.07^{\mathrm{ab}}$ \\
$300(326.5)$ & $78.37 \pm 0.64^{\mathrm{ab}}$ & $14.11 \pm 0.62^{\mathrm{ab}}$ & $4.48 \pm 0.10^{\mathrm{a}}$ & $3.19 \pm 0.10^{\mathrm{ab}}$ \\
$500(549.6)$ & $77.90 \pm 0.57^{\mathrm{ab}}$ & $14.44 \pm 0.19^{\mathrm{ab}}$ & $4.64 \pm 0.17^{\mathrm{a}}$ & $3.46 \pm 0.09^{\mathrm{a}}$ \\
$700(743.9)$ & $77.13 \pm 0.37^{\mathrm{b}}$ & $14.77 \pm 0.06^{\mathrm{a}}$ & $4.86 \pm 0.12^{\mathrm{a}}$ & $3.49 \pm 0.03^{\mathrm{a}}$ \\
$900(938.4)$ & $78.79 \pm 1.58^{\mathrm{ab}}$ & $13.90 \pm 0.94^{\mathrm{ab}}$ & $4.54 \pm 0.29^{\mathrm{a}}$ & $3.38 \pm 0.24^{\mathrm{a}}$ \\
$1100(1118.2)$ & $78.04 \pm 0.64^{\mathrm{ab}}$ & $14.46 \pm 0.42^{\mathrm{ab}}$ & $4.61 \pm 0.02^{\mathrm{a}}$ & $3.37 \pm 0.16^{\mathrm{a}}$ \\
\hline
\end{tabular}

Values represent means $\pm \mathrm{SD}, n=3$. Means in the same column with different superscript letters are significantly different $(P<0.05)$ 
Table 5 Whole-body and vertebrae $\mathrm{Ca}$ and $\mathrm{P}$ concentrations of juvenile hybrid sturgeon fed experimental diets containing different $\mathrm{Mg}$ concentrations for 8 weeks

\begin{tabular}{|c|c|c|c|c|c|c|}
\hline \multirow[t]{2}{*}{$\operatorname{Mg}\left(\mathrm{mg} \mathrm{kg}^{-1}\right)$} & \multicolumn{3}{|l|}{ Whole-body } & \multicolumn{3}{|l|}{ Vertebrae } \\
\hline & $\mathrm{Ca}\left(\mathrm{g} \mathrm{kg}^{-1}\right)$ & $\mathrm{P}\left(\mathrm{g} \mathrm{kg}^{-1}\right)$ & $\mathrm{Ca}: \mathrm{P}$ ratio & $\mathrm{Ca}\left(\mathrm{g} \mathrm{kg}^{-1}\right)$ & $\mathrm{P}\left(\mathrm{g} \mathrm{kg}^{-1}\right)$ & $\mathrm{Ca}: \mathrm{P}$ ratio \\
\hline $0(43.2)$ & $5.88 \pm 0.18$ & $5.81 \pm 0.49$ & $21.14 \pm 0.69^{\mathrm{a}}$ & $161.40 \pm 8.92^{\mathrm{ab}}$ & $141.85 \pm 9.16$ & $81.41 \pm 8.59^{a}$ \\
\hline $100(157.3)$ & $5.94 \pm 0.54$ & $5.46 \pm 0.46$ & $18.54 \pm 1.53^{\mathrm{ab}}$ & $172.09 \pm 14.25^{\mathrm{a}}$ & $136.55 \pm 7.27$ & $80.04 \pm 2.93^{\mathrm{a}}$ \\
\hline $300(326.5)$ & $6.68 \pm 0.20$ & $5.75 \pm 0.42$ & $20.97 \pm 1.71^{\mathrm{a}}$ & $171.81 \pm 7.50^{\mathrm{a}}$ & $137.22 \pm 11.01$ & $76.73 \pm 7.36^{\mathrm{ab}}$ \\
\hline $500(549.6)$ & $6.54 \pm 0.26$ & $6.46 \pm 0.29$ & $17.20 \pm 1.80^{\mathrm{ab}}$ & $172.33 \pm 11.24^{\mathrm{a}}$ & $164.10 \pm 10.60$ & $64.30 \pm 7.26^{\mathrm{abc}}$ \\
\hline $700(743.9)$ & $6.79 \pm 0.09$ & $6.41 \pm 0.29$ & $17.78 \pm 1.27^{\mathrm{ab}}$ & $170.32 \pm 18.70^{\mathrm{a}}$ & $164.12 \pm 11.05$ & $66.95 \pm 4.89^{\mathrm{abc}}$ \\
\hline $900(938.4)$ & $6.09 \pm 0.10$ & $6.47 \pm 0.40$ & $16.05 \pm 1.14^{\mathrm{b}}$ & $158.60 \pm 13.08^{\mathrm{ab}}$ & $162.93 \pm 9.63$ & $60.32 \pm 0.21^{\mathrm{bc}}$ \\
\hline $1100(1118.2)$ & $6.60 \pm 0.36$ & $6.37 \pm 0.44$ & $17.19 \pm 1.44^{\mathrm{ab}}$ & $128.35 \pm 11.18^{\mathrm{b}}$ & $164.83 \pm 9.92$ & $50.33 \pm 5.21^{\mathrm{c}}$ \\
\hline
\end{tabular}

Values represent means $\pm \mathrm{SD}, n=3$. Means in the same column with different superscript letters are significantly different $(P<0.05)$

\section{Whole-body and vertebrae Mg concentrations}

Whole-body and vertebrae Mg concentrations are shown in Figs. 1 and 2. The Mg concentration in the $43.2 \mathrm{mg} \mathrm{kg}^{-1}$ group was significantly lower than that in the 549.6-1118.2 mg $\mathrm{kg}^{-1}$ groups $(P<0.05)$. The whole-body concentrations of $\mathrm{Mg}$ increased with increasing $\mathrm{Mg}$ concentrations and then stabilized after a dietary $\mathrm{Mg}$ concentration of $549.6 \mathrm{mg} \mathrm{kg}^{-1}$ (Fig. 1). The $\mathrm{Mg}$ concentrations of the vertebrae in the 938.4 and $1118.2 \mathrm{mg} \mathrm{kg}^{-1}$ groups were significantly higher than those in the $43.2 \mathrm{mg} \mathrm{kg}^{-1}$ group $(P<0.05)$ (Fig. 2). The optimal dietary $\mathrm{Mg}$ requirement for juvenile hybrid sturgeon was estimated to be 573.6 (Fig. 1) and $584.6 \mathrm{mg} \mathrm{kg}^{-1}$ (Fig. 2) dietary Mg.

\section{Whole-body Mg balance}

The whole-body Mg balances of juvenile hybrid sturgeon fed the experimental diets containing different $\mathrm{Mg}$ levels for 8 weeks are shown in Supplementary material Table S1. The average initial whole-body $\mathrm{Mg}$ content of hybrid sturgeon was $6.95-7.65 \mathrm{mg}$. The final whole-

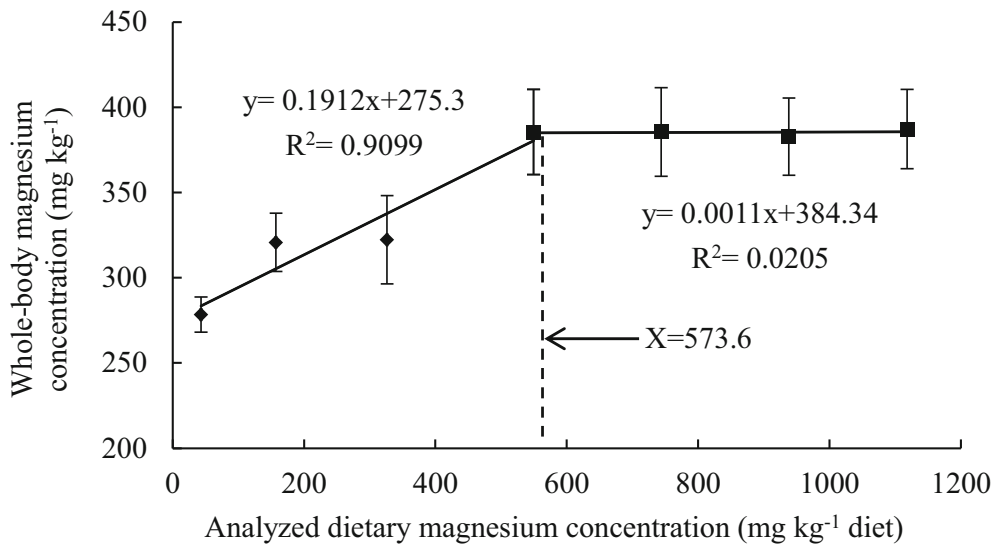

Fig. 1 Relationship between whole-body $\mathrm{Mg}$ concentration and dietary Mg levels of juvenile hybrid sturgeon fed experimental diets for 8 weeks. The breakpoint of the broken line is $573.6 \mathrm{mg} \mathrm{kg}^{-1}$ dietary $\mathrm{Mg}$ 


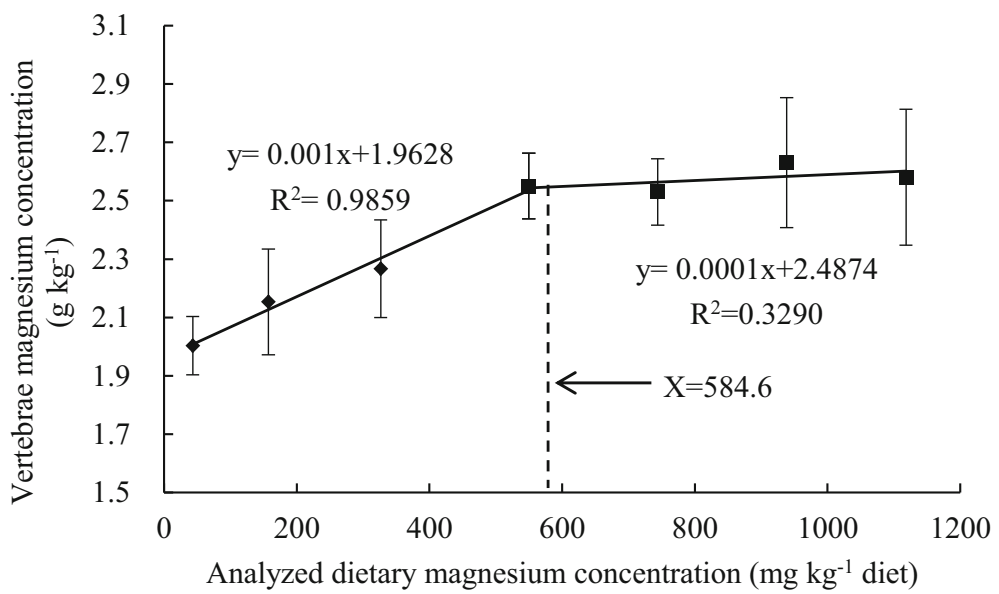

Fig. 2 Relationship between the vertebrae $\mathrm{Mg}$ concentration and dietary $\mathrm{Mg}$ levels of juvenile hybrid sturgeon fed experimental diets for 8 weeks. The breakpoint of the broken line is $584.6 \mathrm{mg} \mathrm{kg}^{-1}$ dietary Mg

body $\mathrm{Mg}$ contents increased as the dietary $\mathrm{Mg}$ levels increased. Whole-body $\mathrm{Mg}$ retention decreased as the dietary $\mathrm{Mg}$ levels increased.

The dietary $\mathrm{Mg}$ requirement for juvenile hybrid sturgeon was estimated and is shown in Fig. 3. Dietary $\mathrm{Mg}$ of $355.16 \mathrm{mg} \mathrm{kg}^{-1}$ was a concentration between the whole-body $\mathrm{Mg}$ retention and the dietary $\mathrm{Mg}$ levels, when the whole-body $\mathrm{Mg}$ retention was $100 \%$.

\section{Antioxidant capacity}

The serum antioxidant levels of hybrid sturgeon fed the experimental diets containing different Mg levels for 8 weeks are shown in Table 6. Serum SOD in the 549.6 to $1118.2 \mathrm{mg} \mathrm{kg}^{-1}$ groups was significantly higher than that in the $43.2 \mathrm{mg} \mathrm{kg}^{-1}$ group $(P<0.05)$ and significantly higher in the 549.6 to $938.4 \mathrm{mg} \mathrm{kg}^{-1}$ groups than in the $157.3 \mathrm{mg} \mathrm{kg}^{-1}$ group $(P<0.05)$. Serum GPx in the 743.9 and $938.4 \mathrm{mg} \mathrm{kg}^{-1}$ groups was significantly higher than that in the other

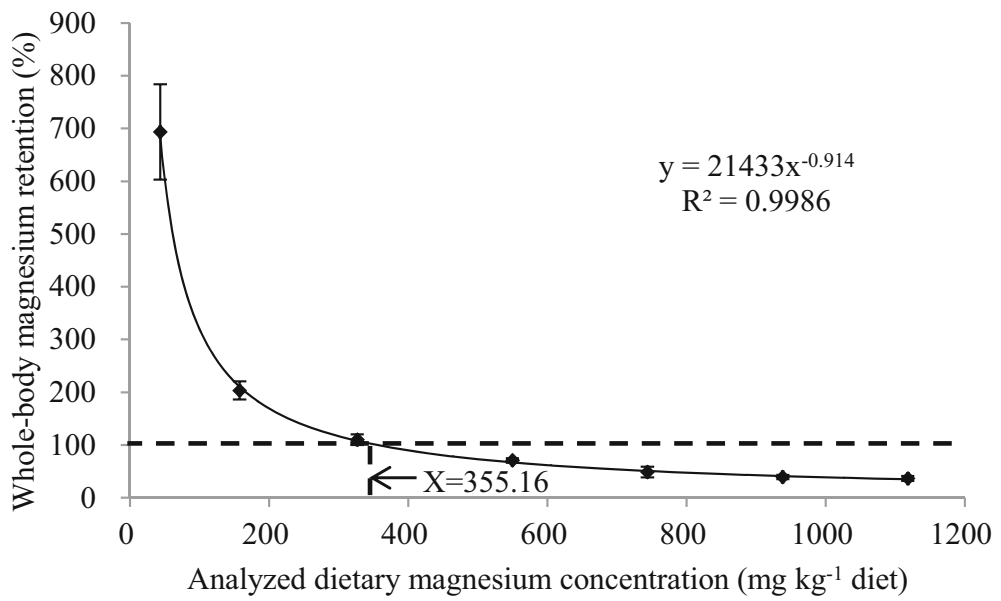

Fig. 3 Relationship between the whole-body $\mathrm{Mg}$ retention and dietary $\mathrm{Mg}$ levels of juvenile hybrid sturgeon fed experimental diets for 8 weeks 
Table 6 Serum antioxidants of hybrid sturgeon fed experimental diets containing different $\mathrm{Mg}$ concentrations for 8 weeks

\begin{tabular}{lllll}
\hline $\begin{array}{l}\mathrm{Mg} \\
\left(\mathrm{mg} \mathrm{kg}^{-1}\right)\end{array}$ & $\begin{array}{l}\mathrm{SOD} \\
\left.(\mathrm{U} \mathrm{mL})^{-1}\right)\end{array}$ & $\begin{array}{l}\mathrm{GPx} \\
\left.(\mathrm{U} \mathrm{mL})^{-1}\right)\end{array}$ & $\begin{array}{l}\mathrm{CAT} \\
\left(\mathrm{U} \mathrm{mL}^{-1}\right)\end{array}$ & $\begin{array}{l}\text { MDA } \\
\left(\mathrm{nmol} \mathrm{mL}^{-1}\right)\end{array}$ \\
\hline $0(43.2)$ & $86.37 \pm 9.72^{\mathrm{d}}$ & $690.76 \pm 16.21^{\mathrm{d}}$ & $1.90 \pm 0.14^{\mathrm{c}}$ & $133.26 \pm 12.45^{\mathrm{a}}$ \\
$100(157.3)$ & $111.93 \pm 13.02^{\mathrm{cd}}$ & $796.64 \pm 45.47^{\mathrm{d}}$ & $1.91 \pm 0.08^{\mathrm{c}}$ & $117.80 \pm 10.50^{\mathrm{a}}$ \\
$300(326.5)$ & $125.84 \pm 12.63^{\mathrm{bcd}}$ & $931.09 \pm 23.71^{\mathrm{c}}$ & $2.21 \pm 0.09^{\mathrm{c}}$ & $73.57 \pm 5.77^{\mathrm{b}}$ \\
$500(549.6)$ & $187.63 \pm 6.96^{\mathrm{a}}$ & $1168.07 \pm 59.47^{\mathrm{b}}$ & $6.08 \pm 0.67^{\mathrm{a}}$ & $36.46 \pm 3.22^{\mathrm{c}}$ \\
$700(743.9)$ & $184.07 \pm 16.26^{\mathrm{a}}$ & $1712.61 \pm 30.85^{\mathrm{a}}$ & $6.05 \pm 0.26^{\mathrm{a}}$ & $50.98 \pm 7.62^{\mathrm{bc}}$ \\
$900(938.4)$ & $161.10 \pm 17.97^{\mathrm{ab}}$ & $1650.42 \pm 54.64^{\mathrm{a}}$ & $3.85 \pm 0.25^{\mathrm{b}}$ & $69.28 \pm 8.45^{\mathrm{b}}$ \\
$1100(1118.2)$ & $150.42 \pm 14.10^{\mathrm{abc}}$ & $1050.42 \pm 49.60^{\mathrm{bc}}$ & $4.41 \pm 0.27^{\mathrm{b}}$ & $72.48 \pm 6.78^{\mathrm{b}}$ \\
\hline
\end{tabular}

Values represent means $\pm \mathrm{SD}, n=3$. Means in the same column with different superscript letters are significantly different $(P<0.05)$

$\ddagger U$ activity unit of enzyme

groups $(P<0.05)$ and was significantly higher in the $326.5,549.6$, and $1118.2 \mathrm{mg} \mathrm{kg}^{-1}$ groups than in the 43.2 and $157.3 \mathrm{mg} \mathrm{kg}^{-1}$ groups $(P<0.05)$. Serum CAT was significantly higher in the 549.6 and $743.9 \mathrm{mg} \mathrm{kg}^{-1}$ groups than in the other groups $(P<0.05)$ and significantly higher in the 938.4 and $1118.2 \mathrm{mg} \mathrm{kg}^{-1}$ groups than in the $43.2,157.3$, and $326.5 \mathrm{mg} \mathrm{kg}^{-1}$ groups $(P<0.05)$. Serum MDA in the 43.2 and $157.3 \mathrm{mg} \mathrm{kg}^{-1}$ groups was significantly higher than that in the other groups $(P<0.05)$ and significantly higher in the 326.5, 938.4, and $1118.2 \mathrm{mg} \mathrm{kg}^{-1}$ groups than in the $549.6 \mathrm{mg} \mathrm{kg}^{-1}$ groups $(P<0.05)$.

\section{Discussion}

The requirements of Mg previously reported for freshwater fish were 326-1400 mg kg-1 diet (Ogino et al. 1978; Knox et al. 1981; Gatlin et al. 1982; Shim and Ng 1988; Shearer 1989; Reigh et al. 1991; El-Mowafi and Maage 1998), which was the basis for setting the doses of $\mathrm{Mg}$ in this study. An isotopic study found that when $\mathrm{Mg}$ in food was insufficient, fish were able to absorb some $\mathrm{Mg}$ from water; when the $\mathrm{Mg}$ concentration in food is too high, fish will excrete redundant Mg via the skin (Bijvelds et al. 1996; Wang et al., 2011). These processes could regulate the $\mathrm{Mg}$ balance. In the current study, the whole-body $\mathrm{Mg}$ concentration (573.6 $\mathrm{mg} \mathrm{kg}^{-1}$ diet of $\mathrm{Mg}$ ), the vertebrae $\mathrm{Mg}$ concentration (584.6 $\mathrm{mg} \mathrm{kg}^{-1}$ diet of $\mathrm{Mg}$ ), and the whole-body $\mathrm{Mg}$ retention (355.16 $\mathrm{mg} \mathrm{kg}^{-1}$ diet $\mathrm{Mg}$ ) were used to estimate the dietary $\mathrm{Mg}$ requirement of grass carp. This value is similar to that reported for other fish from 326 to $745 \mathrm{mg} \mathrm{kg}^{-1}$ diet (Ogino and Chiou 1976; Ogino et al. 1978; Knox et al. 1981; Shim and Ng 1988; Reigh et al. 1991; El-Mowafi and Maage 1998; Duan et al., 2012).

There are differences in reports on the effect of $\mathrm{Mg}$ requirement on growth performance. Reigh et al. (1991) reported a positive response to $30-650 \mathrm{mg} \mathrm{kg}^{-1}$ diet $\mathrm{Mg}$ supplementation of blue tilapia (Oreochromis aureus) fed casein-based diets in terms of their growth, feed, and protein efficiency. A lack of $\mathrm{Mg}$ in the feed can dull appetite, slow growth, increase mortality, and significantly decrease the production performance in aquatic animals (Ogino and Chiou 1976; Cowey 1976; Cowey et al. 1976; Cowey et al. 1977; Knox et al. 1981; Gatlin et al. 1982; Shim and Ng 1988; Shearer 1989; Reigh et al. 1991; Wei et al. 2017; Mohammad and Khan 2018). Not all fish respond well in terms of growth to dietary Mg, such as Atlantic salmon (Salmo salar L.) (El-Mowafi and Maage 1998), tilapia (Oreochromis mossambicus (Peters)) (Velden et al. 1991), grass carp (Ctenopharyngodon 
idella) (Wang et al., 2011), and gibel carp (Han et al. 2012). In the current study, dietary Mg (from 43.2 to $1118.2 \mathrm{mg} \mathrm{kg}^{-1}$ ) did not significantly impact the growth performance of juvenile hybrid sturgeon.

Wang et al. (2011) found that adding an appropriate amount of $\mathrm{Mg}$ sulfate to the diet significantly increased the whole-body crude protein in fish. Compared with the $43.2 \mathrm{mg} \mathrm{kg} \mathrm{g}^{-1}$ diet $\mathrm{Mg}$ group, treatment groups, such as $743.9 \mathrm{mg} \mathrm{kg}^{-1}$ diet $\mathrm{Mg}$ in whole-body crude protein contents, $157.3-1118.2 \mathrm{mg} \mathrm{kg}^{-1}$ diet Mg in whole-body crude fat contents, and 549.6-1118.2 mg $\mathrm{kg}^{-1}$ diet $\mathrm{Mg}$ in whole-body ash contents, were significantly increased in the current study.

The whole-body $\mathrm{Ca}$ and $\mathrm{P}$ concentrations in rainbow trout (Oncorhynchus mykiss) fed low $\mathrm{Mg}$ diets were considerably higher than those fed normal diets (Shearer 1984), suggesting that $\mathrm{Ca}$ and $\mathrm{P}$ levels associated with $\mathrm{Mg}$ status. The Ca content in the bones or whole body of fish fed with low-Mg diets was significantly higher than that in guppy (Poecilia reticulata (Peters)), rainbow trout, and blue tilapia fed with normal diets (Shim and $\mathrm{Ng} \mathrm{1988;} \mathrm{Shearer}$ 1989; Reigh et al. 1991). In our results, whole-body $\mathrm{Ca}$ and $\mathrm{P}$ concentrations were not influenced by $\mathrm{Mg}$ concentrations, and $938.4 \mathrm{mg} \mathrm{kg}^{-1}$ diet $\mathrm{Mg}$ in Ca:P ratio of whole-body mineral concentrations was significantly lower than $938.4 \mathrm{mg} \mathrm{kg}^{-1}$ diet $\mathrm{Mg}$, which may be due to the difference in species. The vertebrae Ca content was affected by the dietary $\mathrm{Mg}$ levels (Ogino and Chiou, 1976). Our results showed that moderate Mg concentrations (157.3$743.9 \mathrm{mg} \mathrm{kg}^{-1}$ ) increased vertebrae Ca concentrations compared with $1118.2 \mathrm{mg} \mathrm{kg}^{-1}$ diet $\mathrm{Mg}$, and the $\mathrm{Ca}: \mathrm{P}$ ratios in the lower $\mathrm{Mg}$ concentration groups of vertebrae (dietary 43.2 and $157.3 \mathrm{mg} \mathrm{kg}^{-1}$ ) were higher than those in 938.4 and $1118.2 \mathrm{mg} \mathrm{kg}^{-1}$ diet $\mathrm{Mg}$, which indicated that low $\mathrm{Mg}$ concentrations were beneficial to the deposition of $\mathrm{Ca}$ and $\mathrm{P}$.

A variety of antioxidant defense systems have evolved in organisms. Antioxidant systems include enzymes, such as SOD, CAT, and GPx, to constantly suppress and remove the production of oxidative stress. In the current study, serum SOD and CAT activities were significantly higher in the 549.6 and $743.9 \mathrm{mg} \mathrm{kg}^{-1}$ groups than in the other groups and the serum GPx activities were significantly higher in the 743.9 and $938.4 \mathrm{mg} \mathrm{kg}^{-1}$ groups than in the other groups. These results indicated that appropriate $\mathrm{Mg}$ levels enhanced the antioxidant capacity; this observation is supported by Garcia et al. (1998), who found that $\mathrm{Mg}$ can reduce the production of free radicals. $\mathrm{Mg}$ can eradicate free radicals by enhancing antioxidant enzyme activities, such as those of SOD, CAT, and GPx, and this phenomenon might explain the effectiveness of Mg against peroxidation (Mohammad and Khan 2018). Wang et al. (2011) documented that grass carp fed imbalanced $\mathrm{Mg}$ levels were susceptible to lipid peroxidation as a result of reduced serum SOD and GPx activities, suggesting reduced antioxidant capacity in response to dietary Mg deficiency (Mohammad and Khan 2018). As an essential cofactor in glutathione biosynthesis, $\mathrm{Mg}$ can inhibit lipid peroxidation by preventing exhaustion of glutathione, which showed similar results as the serum GPx activity in response to low-Mg diets (Zhang et al. 2016). In the current study, the activities of SOD, CAT, and GPx were positively correlated with the concentration of $\mathrm{Mg}$. MDA is the final product of lipid peroxidation and an important indicator of membrane injury caused by free radicals (Longbaf Dezfouli et al. 2019). Mohammad and Khan (2018) reported that the antioxidant status of Rohu improved with the inclusion of dietary $\mathrm{Mg}$ levels up to $460 \mathrm{mg} \mathrm{kg}^{-1}$ diet and then stabilized in groups fed higher levels of $\mathrm{Mg}$, whereas the reverse pattern was observed for the MDA content. In the current study, the MDA contents in the $549.6 \mathrm{mg} \mathrm{kg}^{-1}$ groups were significantly lower than those in the 43.2, 157.3, 326.5, 938.4, and $1118.2 \mathrm{mg} \mathrm{kg}^{-1}$ groups, suggesting that the antioxidative effect of $\mathrm{Mg}$ results from its ability to increase the activity of radical-scavenging enzymes and decrease the peroxidation of lipids. 


\section{Conclusion}

In summary, although dietary $\mathrm{Mg}$ concentrations had no effect on growth performance, the optimal amount of $\mathrm{Mg}$ supplementation improved dietary crude protein content, crude fat content, and whole-body Mg concentration; enhanced serum SOD, GPx, and CAT activities; and decreased serum MDA contents in juvenile hybrid sturgeon. Thus, a dietary Mg concentration of $350-700 \mathrm{mg} \mathrm{kg}^{-1}$ is suggested as a recommended dosage for the aquaculture of juvenile hybrid sturgeon.

Supplementary Information The online version contains supplementary material available at https://doi.org/ 10.1007/s10499-021-00712-7.

Author contribution Zhang and Wang conceived and designed the experiments; Zhang, Fan, and Wu performed the experiments; Zhang and $\mathrm{Li}$ analyzed the data; and Zhang, $\mathrm{Xu}$, and Liu wrote and modified the paper.

Funding This research was supported by the National Key R \& D Program of China, Grant/Award Number (2019YFD0900200), the China Agricultural Research System (CARS-46), Central Public-interest Scientific Institution Basal Research Fund (HSY202002M), the Financial Assistance from Postdoctoral Scientific Research Developmental Fund of Heilongjiang Province (LBHQ20193).

Data availability The data used to support the findings of this study are available from the corresponding author upon request.

\section{Declarations}

Ethical approval All applicable international, national, and/or institutional guidelines for the care and use of animals were followed by the authors.

Conflict of interest The authors declare no competing interests.

Open Access This article is licensed under a Creative Commons Attribution 4.0 International License, which permits use, sharing, adaptation, distribution and reproduction in any medium or format, as long as you give appropriate credit to the original author(s) and the source, provide a link to the Creative Commons licence, and indicate if changes were made. The images or other third party material in this article are included in the article's Creative Commons licence, unless indicated otherwise in a credit line to the material. If material is not included in the article's Creative Commons licence and your intended use is not permitted by statutory regulation or exceeds the permitted use, you will need to obtain permission directly from the copyright holder. To view a copy of this licence, visit http://creativecommons.org/licenses/by/4.0/.

\section{References}

AOAC (1995) Official methods of analysis, 16th edn. Association of Official Analytical Chemists, Washington Bijvelds MJC, Flik G, Kolar ZI, Bonga SW (1996) Uptake, distribution and excretion of magnesium in Oreochromis mossambicus: dependence on magnesium in diet and water. Fish Physiol Biochem 15(4): 287-298. https://doi.org/10.1007/BF02112355

Bijvelds MJC, Flik G, Bonga SW (1997) Mineral balance in Oreochromis mossambicus: dependence on magnesium in diet and water. Fish Physiol Biochem 16(4):323-331. https://doi.org/10.1023/A: 1007727819382

CFSY (2018) China Fishery Statistical Yearbook, vol 25. Beijing China Statistics Press, Beijing 
Cowey CB (1976) Use of synthetic diets and biochemical criteria in the assessment of nutrient requirements of fish. J Fish Res Board Can 33(4):1040-1045. https://doi.org/10.1139/f76-132

Cowey CB, Coombs TL, Adron JW (1976) The renal and serum concentrations of calcium, magnesium and phosphorus in captive and wild turbot (Scophthalmus maximus). Mar Biol 38(2):111-115. https://doi.org/10. 1007/BF00390764

Cowey CB, Knox D, Adron JW, George S, Pirie B (1977) The production of renal calcinosis by magnesium deficiency in rainbow trout (Salmo gairdneri). Brit J Nutr 38(1):127-135. https://doi.org/10.1079/ BJN19770068

Davis DA, Gatlin DM (1996) Dietary mineral requirements of fish and marine crustaceans. Rev Fish Sci 4(1):7599. https://doi.org/10.1080/10641269609388579

Duan Y, Zhu X, Han D, Yang Y, Xie S (2012) Dietary choline requirement in slight methionine-deficient diet for juvenile gibel carp (Carassius auratus gibelio). Aquac Nutr 18(6):620-627. https://doi.org/10.1111/j.13652095.2011.00930.x

El-Mowafi AFA, Maage A (1998) Magnesium requirement of Atlantic salmon (Salmo salar L.) parr in seawatertreated fresh water. Aquac Nutr 4(1):31-38. https://doi.org/10.1046/j.1365-2095.1998.00100.x

Garcia LA, Dejong SC, Martin SM, Smith RS, Buettner GR, Kerber RE (1998) Magnesium reduces free radicals in an in vivo coronary occlusion-reperfusion model. J Am Coll Cardiol 32(2):536-539. https://doi.org/10. 1016/S0735-1097(98)00231-9

Gatlin DM 3rd, Robinson EH, Poe WE, Wilson RP (1982) Magnesium requirement of fingerling channel catfish and signs of magnesium deficiency. J Nutr 112(6):1182-1187. https://doi.org/10.1093/jn/112.6.1182

Han D, Liu H, Liu M, Xiao X, Zhu X, Yang Y, Xie S (2012) Effect of dietary magnesium supplementation on the growth performance of juvenile gibel carp, Carassius auratus gibelio. Aquac Nutr 18(5):512-520. https://doi.org/10.1111/j.1365-2095.2011.00910.x

Knox D, Cowey CB, Adron JW (1981) Studies on the nutrition of salmonid fish. The magnesium requirement of rainbow trout (Salmo gairdneri). Brit J Nutr 45(1):137-148. https://doi.org/10.1079/BJN19810086

Lall SP (2002) The Minerals. In: Halver JE, Hardy RW (eds) Fish nutrition, 3rd edn. Elsevier, Amsterdam, pp 259-308

Liang JJ, Tian LX, Liu YJ, Yang HJ, Liang GY (2011) Dietary magnesium requirement and effects on growth and tissue magnesium content of juvenile grass carp (Ctenopharyngodon idella). Aquac Nutr 18(1):56-64. https://doi.org/10.1111/j.1365-2095.2011.00876.x

Liang MQ, Wei YL, Tan F, Zheng KK, Xu HG (2015) The effects of dietary magnesium (Mg) supplementation on growth performance of adult Japanese seabass (Lateolabrax japonicas). Isr J Aquacult-Bamid 67:11701179 http://hdl.handle.net/10524/49189

Lin YH, Ku CY, Shiau SY (2013) Estimation of dietary magnesium requirements of juvenile tilapia, Oreochromis niloticus $x$ Oreochromis aureus, reared in freshwater and seawater. Aquaculture 380-383: 47-51. https://doi.org/10.1016/j.aquaculture.2012.11.034

Longbaf Dezfouli M, Ghaedtaheri A, Keyvanshokooh S, Salati AP, Mousavi SM, Pasha-Zanoosi H (2019) Combined or individual effects of dietary magnesium and selenium nanoparticles on growth performance, immunity, blood biochemistry and antioxidant status of Asian seabass (Lates calcarifer) reared in freshwater. Aquac Nutr 25:1422-1430. https://doi.org/10.1111/anu.12962

Mohammad M, Khan MA (2018) Dietary magnesium requirement for fingerlings of Rohu (Labeo rohita). Aquaculture 496:96-104. https://doi.org/10.1016/j.aquaculture.2018.07.013

Nthunya L, Maifadi S, Mamba B, Verliefde A, Mhlanga S (2018) Spectroscopic determination of water salinity in brackish surface water in Nandoni Dam, at Vhembe District, Limpopo Province, South Africa. Water 10: 990-1003. https://doi.org/10.3390/w10080990

Ogino C, Chiou JY (1976) Mineral requirements in fish, 2: magnesium requirement of carp. Bull Jap Soc Sci Fish 42(1):71-75. https://doi.org/10.2331/suisan.42.71

Ogino C, Takashima F, Chiou JY (1978) Requirement of rainbow trout for dietary magnesium. Nippon Suisan Gakkaishi 44(10):1105-1108. https://doi.org/10.2331/suisan.44.1105

Reigh RC, Robinson EH, Brown PB (1991) Effects of dietary magnesium on growth and tissue magnesium content of blue tilapia Oreochromis aureus. J World Aquacult Soc 22(3):192-200. https://doi.org/10.1111/j. 1749-7345.1991.tb00734.x

Robbins KR, Norton HW, Baker DH (1979) Estimation of nutrient requirements from growth data. J Nutr 109(10):1710-1714. https://doi.org/10.1093/jn/109.10.1710

Sakamoto S, Yone Y (1979) Requirement of red sea bream for dietary Mg. Bull Jap Soc Sci Fish 45(1):57-60. https://doi.org/10.2331/suisan.45.57

Shearer KD (1984) Changes in elemental composition of hatchery-reared rainbow trout, Salmo gairdneri, associated with growth and reproduction. Can J Fish Aquat Sci 41(11):1592-1600. https://doi.org/10. 1139/f84-197 
Shearer KD (1989) Whole body magnesium concentration as an indicator of magnesium status in rainbow trout (Salmo gairdneri). Aquaculture 77(2-3):201-210. https://doi.org/10.1016/0044-8486(89)90202-0

Shim KF, Ng SH (1988) Magnesium requirement of the guppy (Poecilia reticulata Peters). Aquaculture 73(1-4): 131-141. https://doi.org/10.1016/0044-8486(88)90048-8

Tam M, Gomez S, Gonzalez-Gross M, Marcos A (2003) Possible roles of magnesium on the immune system. Eur J Clin Nutr 57(10):1193-1197. https://doi.org/10.1038/sj.ejcn.1601689

Velden JAVD, Spanings FAT, Flik G, Zegers C, Kolar ZI, Bongat SW (1991) Growth rate and tissue magnesium concentration in adult freshwater tilapia, Oreochromis mossambicus (Peters), fed diets differing in magnesium content. J Fish Biol 39:83-91. https://doi.org/10.1111/j.1095-8649.1991.tb04343.x

Vormann J (2003) Magnesium: nutrition and metabolism. Mol Asp Med 24(1-3):27-37. https://doi.org/10.1016/ S0098-2997(02)00089-4

Wang FB, Luo L, Lin SM, Li Y, Chen S, Wang YG, Wen H, Hu CJ (2011) Dietary magnesium requirements of juvenile grass carp, Ctenopharyngodon idella. Aquac Nutr 17(3):691-700. https://doi.org/10.1111/j.13652095.2010.00829.x

Wei CC, Wu K, Gao Y, Zhang LH, Li DD, Luo Z (2017) Magnesium reduces hepatic lipid accumulation in yellow catfish (Pelteobagrus fulvidraco) and modulates lipogenesis and lipolysis via PPARA, JAK-STAT, and AMPK pathways in hepatocytes. J Nutr 147(6):1070-1078. https://doi.org/10.3945/jn.116.245852

Ye CX, Tian LX, Mai KS, Yang HJ, Niu J, Liu YJ (2010) Dietary magnesium did not affect calcium and phosphorus content in juvenile grouper, Epinephelus coioides. Aquac Nutr 16(4):378-384. https://doi.org/ 10.1111/j.1365-2095.2009.00675.x

Zhang CX, Huang F, Li J, Wang L, Song K, Mai KS (2016) Interactive effects of dietary magnesium and vitamin E on growth performance, body composition, blood parameters and antioxidant status in Japanese seabass (Lateolabrax japonicus) fed oxidized oil. Aquac Nutr 22(3):708-722. https://doi.org/10.1111/anu.12393

Publisher's note Springer Nature remains neutral with regard to jurisdictional claims in published maps and institutional affiliations.

\section{Affiliations}

\section{Yuanyuan Zhang ${ }^{1} \cdot \mathrm{Ze} \mathrm{Fan}^{1} \cdot \mathrm{Di} \mathrm{Wu}{ }^{1} \cdot \mathrm{Jinnan} \mathrm{Li}^{1} \cdot$ Qiyou Xu ${ }^{1,2} \cdot \mathrm{Hongbai}^{\mathrm{Liu}}{ }^{1} \cdot$ Liansheng Wang ${ }^{1}$}

1 Key Laboratory of Aquatic Animal Diseases and Immune Technology of Heilongjiang Province, Heilongjiang River Fisheries Research Institute, Chinese Academy of Fishery Sciences, Harbin 150070, China

2 School of Life Science, Huzhou University, Huzhou 313000, China 